7 Corresponding author: *lacaadriana@uniovi.es

\title{
SURVIVAL AND DEVELOPMENT OF STAPHYLOCOCCUS IN EGG PRODUCTS
}

\author{
Marta Sánchez, Carmen Neira, Amanda Laca, Adriana Laca*, Mario Díaz
}

Department of Chemical and Environmental Engineering.

University of Oviedo. C/ Julián Clavería s/n. 33071 Oviedo. Spain.

8

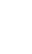

\begin{abstract}
In this work, Staphylococcus has been employed to simulate a contamination of different egg foodstuffs. Liquid (egg white, egg yolk and whole egg) and also solid (Spanish potato omelette) products have been employed as model foods. The effect of different parameters, i.e. oxygen availability, cooking temperature and storage temperature, on microorganism survival and development has been evaluated. In addition, the structure of solid foods has been analysed by means of rheological measurements.
\end{abstract}

Results showed that Staphylococcus behaviour in liquid media was strongly influenced by the oxygen concentration, which is determinant for the specific growth rates $(\mu)$. In solid foods, the increase of cooking temperature to $100^{\circ} \mathrm{C}$ reduced the microbial viability by one order of magnitude with respect to the raw foodstuff. Additionally, it was observed that the structure of the omelette, which depended on the cooking temperature, was a key parameter regarding the $\mu$ values. Therefore, to avoid the risk of food poisoning by Staphylococcus proliferation, in the case of egg products cooked only for few minutes, the cooking temperature should be higher than $100^{\circ} \mathrm{C}$ and 
the subsequent storage should be at refrigeration temperatures that increase the lag phase and decrease the growth rate.

Key words: egg products; food safety; omelette; rheology; Staphylococcus.

\section{INTRODUCTION}

Hen eggs are used as an economical source of high quality proteins commercialised in the form of shell eggs, but also liquid, frozen, and dried products (Muñoz et al., 2015; Upadhyaya et al., 2017). In addition, as one of the most versatile products, eggs are widely used in food industries on account of its functional attributes such as foaming, emulsifying, gelling, colouring and flavouring properties (Lechevalier et al., 2017).

World egg production and consumption have been increasing for the past decades (Abín et al., 2018), and current issues, such as food safety, should be considered in modern egg production (Wang et al., 2017a). Shell eggs can be contaminated with many types of microorganisms (Neira et al., 2017), including pathogens, and, thus, they present a risk for the transmission of foodborne disease to consumers (Al-Ajeeli et al., 2016). In fact, consumption of eggs and egg products has been often linked to food poisoning outbreaks due to their contamination with pathogenic bacteria (Moyle et al., 2016; Muñoz et al., 2015). In Spain, almost $40 \%$ of the outbreaks notified are related to consumption of eggs or derivative products. Thus, this is the most significant sector within food industry to study regarding the prevention of foodborne diseases.

Microbiological quality and safety of egg and egg products is largely subject to adequate cooking, handling, cooling and storing. It is well known that cooking temperature is a key factor regarding egg and egg derivatives safety. Indeed, it is 
recommended that eggs should be cooked until the whites and yolks are coagulated and,

51 in case of dishes containing fresh eggs a temperature of $75^{\circ} \mathrm{C}$ should be reached (R.D. 1254/1991). Nevertheless, in many households and even in many eating establishments, egg products are consumed without being totally cooked as, for example, soft-boiled eggs or "runny" omelettes, which increases food poisoning risks.

Epidemiological studies show that eggs are important sources for consumers' exposure to pathogens. Specifically, Salmonella and Campylobacter have received much attention and the incidence of these genera in eggs and eggs products has been thoroughly analysed (Alter, 2017; Gast and Jones, 2017; Jonaidi-Jafari et la., 2016; Kaldhone et al., 2017; Martelli et al., 2017; Messelhäusser et al., 2011). Additionally, 60 some attempts have been carried out to study the behaviour in egg products of 61 microorganism such as Bacillus, Serratia, Staphylococcus or Pseudomonas (Ananou et al., 2018; De Reu et al., 2006). Staphylococcus spp. is well known to produce a wide variety of toxins and it has also been described as a genus with ability to form amines, which, due to its toxicological characteristics, are responsible of outbreaks of food poisoning (Wang et al., 2017b). So, the prevention of Staphylococcus proliferation is an 66 issue of great interest. However, few attention has been paid in literature to Staphylococcus in relation with egg products and, as far as we know, none work has been carried out in solid egg foodstuffs.

Hence, in the present work, Staphylococcus has been employed to simulate a contamination of liquid and solid egg products. The evolution of this bacteria has been monitored to evaluate the effect of different conditions of cooking and storage. In addition, the effect of oxygen availability has also been analysed. In all cases the specific growth rate $(\mu)$ values were obtained and compared in order to evaluate the Staphylococcus behaviour. Finally, the structure of the model omelette was evaluated by 
means of rheological measurements with the aim to identify possible effects of structure on microorganism growth.

\section{MATERIALS AND METHODS}

\subsection{Microorganism}

Staphylococcus warneri (CECT 236) acquired from the Spanish Collection of Type Cultures was employed as model bacterium.

\subsection{Culture media and experimental conditions}

Shell eggs and potatoes were purchased at a local supermarket.

\subsubsection{Liquid model food: white-, yolk- and egg- medium}

For preparing the medium, egg white, egg yolk or whole egg was diluted in distilled water in sterile conditions $(10 \% \mathrm{v} / \mathrm{v})$. The inoculum was prepared by transferring a loopful of refrigerated working cultures on Petri dishes to $500 \mathrm{~mL}$ Erlenmeyer flasks containing $100 \mathrm{~mL}$ of each medium.

The white- and yolk- medium were incubated under aerobic conditions $(250 \mathrm{rpm})$, whereas three types of experimental conditions were assayed for the whole eggmedium:

- Aerobic conditions (7.8-8.2 mg/L dissolved oxygen): $0.5 \mathrm{~L}$ Erlenmeyer flasks containing $100 \mathrm{ml}$ of inoculated medium were incubated at $250 \mathrm{rpm}$.

- Hypoxic conditions (4.1-6.9 mg/L dissolved oxygen): $100 \mathrm{~mL}$ full bottles closed with screw tops were cultured without shaking.

- Anoxic conditions $(<1 \mathrm{mg} / \mathrm{L}$ dissolved oxygen): the conditions described for hypoxic conditions were also employed, but, in this case, the initial dissolved oxygen was removed from the medium by flushing sterile nitrogen. 
The white- and yolk- medium were incubated under three different temperatures

$102\left(11,25\right.$ and $\left.37^{\circ} \mathrm{C}\right)$, whereas egg-medium experiments were carried out at $20^{\circ} \mathrm{C}$.

103 The growth of Staphylococcus was determined by plating samples taken at different

104 times on Nutrient Broth Agar (Biokar).

$105 \quad$ 2.2.2 Structured model food: Spanish potato omelette

106 The preinoculum was prepared from a refrigerated stock of Petri dishes by

107 transferring a loopful of the cultures to $500 \mathrm{~mL}$ Erlenmeyer flasks containing $100 \mathrm{~mL}$ of

108 Nutrient Broth. After 24 hours of incubation, $2 \mathrm{~mL}$ of this culture were centrifuged

109 (13000 rpm, $5 \mathrm{~min})$ and the pellet was resuspended in saline solution $(\mathrm{NaCl} 0.9 \% \mathrm{v} / \mathrm{v})$

110 and centrifuged again. The raw omelette medium was prepared in sterile conditions by

111 stomaching the preinoculum pellet resuspended in $20 \mathrm{~mL}$ of whole liquid egg and $30 \mathrm{~g}$

112 of small boiled-potato pieces. The initial concentration of microorganism was

113 approximately $10^{7} \mathrm{CFU} / \mathrm{g}$. Sterile $12 \mathrm{~mL}$ syringe-bodies $(1.5 \mathrm{~cm}$ in diameter and $7.6 \mathrm{~cm}$

114 in length) were packed with this mixture, reaching inside $4 \mathrm{~cm}$ in height. Then, the

115 syringes were closed by placing sterile aluminium foil sealed with Teflon ${ }^{\circledR}$ at the

116 syringe tip and a cotton wool plug on the top (Noriega et al., 2010a). Syringes so

117 prepared were placed during $8 \mathrm{~min}$ in an oven at different temperatures $(60,80$ and

$118100^{\circ} \mathrm{C}$ ) to simulate the omelette cooking. Finally, the syringes were incubated at

119 different temperatures $\left(6,20\right.$ and $\left.30^{\circ} \mathrm{C}\right)$ to simulate different storage conditions. The

120 employment of syringes as containers mimics the environmental conditions at the

121 surface and different depths of a real omelette.

122 Sampling was carried out by taking $1 \mathrm{~g}$ of the model omelette at different 123 longitudinal positions: $3.7-4.0 \mathrm{~cm}$ (surface), $2.0-2.3 \mathrm{~cm}$ (middle) and $0.0-0.3 \mathrm{~cm}$

124 (bottom) (Figure 1). All samples were taken in triplicate. Each sample was transferred

125 to a stomacher bag and homogenized with $9 \mathrm{~mL}$ of sterile saline solution and after that 
serial decimal dilutions of the mixture were plated in triplicate onto Nutrient Broth Agar

127 and incubated at $30{ }^{\circ} \mathrm{C}$ for $48 \mathrm{~h}$ before counting.

128

\subsection{Characterization of the structured media}

\subsubsection{Reometry}

Rheological measurements were carried out employing a Haake MARS II rotational rheometer. A plate/plate measuring system (PP60Ti) with a gap of $1 \mathrm{~mm}$ was used. All tests were carried out at $20 \pm 0.1{ }^{\circ} \mathrm{C}$. Before measuring, samples rested for at least 15 min to allow the stresses induced during sample loading to relax (Laca et al., 2010a). The frequency sweeps were carried out from 0.1 to $10 \mathrm{~Hz}$ at a constant shear stress of 5 Pa.

\subsubsection{Microscopy}

The model omelettes were observed after inoculation by optical microscopy (Olympus BX61).

\section{RESULTS AND DISCUSSION}

\subsection{Liquid model foods: white-, yolk- and egg - medium}

\subsubsection{Effect of composition}

In Figure 2 it can be observed the behaviour of $S$. warneri in liquid yolk- and whitemedium at $37^{\circ} \mathrm{C}$. It should be noticed that there was no growth in white-medium at the optimum temperature of the bacteria $\left(37^{\circ} \mathrm{C}\right)$. Indeed, the viability decreased from the first hours and, after 25 hours, viable microorganisms were not detected in the medium. This can be explained due to the characteristic composition of egg white, since albumen proteins, mainly lysozyme and ovotransferrin, are well known to play important antimicrobial roles. Specifically, Bedrani et al. (2013) found that these both proteins 
152 exhibit antimicrobial activity against S. aureus. Furthermore, several additional minor

153 proteins and peptides have also been reported as potential protectors against bacterial 154 contamination (Bedrani et al., 2013; Baron et al., 2016).

155 Figure 3 shows the behaviour of $S$. warneri in the medium prepared with whole egg 156 (yolk and albumen) at different oxygen concentrations at $20^{\circ} \mathrm{C}$. From Figures 2 and 3 , it

157 can be compared the growth of Staphylococcus in yolk- and in egg-medium in aerobic 158 conditions and at room temperature $\left(20-25^{\circ} \mathrm{C}\right)$. Although in both cases a notable growth 159 is observed, the CFU increased in three orders of magnitude in the case of yolk (from

$1603 \times 10^{5}$ to $10^{8} \mathrm{CFU} / \mathrm{mL}$ ), whereas in egg-medium the increment was only in two orders of 161 magnitude (from $2 \times 10^{5}$ to $10^{7} \mathrm{CFU} / \mathrm{mL}$ ). Other difference was, the lag phase that lasted 162 approximately $3 \mathrm{~h}$ in the case of whole egg and $10 \mathrm{~h}$ in yolk-medium. The exponential 163 phase was also very different in both cases, whereas a sharp slope was observed during 164 the exponential growth of the bacteria in yolk-medium, the slope was much more 165 moderate in egg-medium. Indeed, this is clearly reflected by the specific growth rate 166 values: $0.3172 \mathrm{~h}^{-1}$ and $0.0837 \mathrm{~h}^{-1}$ for yolk- and egg- medium, respectively (Table 1).

167 Additionally, the necessary time to achieve the stationary phase of growth was shorter 168 for yolk-medium $(\sim 15 \mathrm{~h})$ than for egg-media $(\sim 50 \mathrm{~h})$.

$169 \quad$ 3.1.2 $\quad$ Effect of temperature

170 Yolk resulted an accurate medium for S. warneri survival at all the assayed 171 temperatures. At $11{ }^{\circ} \mathrm{C}$ the culture maintained its viability, however the cell growth was 172 negligible and the microorganism concentrations remained around $3 \times 10^{5} \mathrm{CFU} / \mathrm{ml}$ 173 during the 3 days that lasted the experiment. On the contrary, bacteria increased 174 approximately in three orders of magnitude when the incubation was at $25^{\circ} \mathrm{C}$ and at $17537^{\circ} \mathrm{C}$. However, the differences of growth due to temperature can be easily observed 176 when the specific growth rates are compared (Table 1). It was impossible to obtain $\mu$ 
177 from the experiment at $11^{\circ} \mathrm{C}$ since no exponential phase was found. Nevertheless, the

178 values obtained at 25 and $37^{\circ} \mathrm{C}$ were 0.2810 and $0.3172 \mathrm{~h}^{-1}$, respectively, which clearly

179 indicates that the rate of growth was higher for higher temperature. Furthermore, the lag

180 phase was also different depending on temperature, it lasts $10 \mathrm{~h}$ at $25^{\circ} \mathrm{C}$, whereas there

181 was non-existent at $37^{\circ} \mathrm{C}$.

$182 \quad$ 3.1.3 Effect of oxygen concentration

183 Due to its relatively low solubility in water, oxygen is the substrate most likely

184 to limit microbial growth in liquid products, but especially in solid foods, where the

185 presence of diffusional limitations plays an important role. Different works about the

186 conditions and mechanisms that govern the growth, survival and proliferation of

187 facultative bacteria, such as Listeria, in low $\mathrm{O}_{2}$ food environments have been carried out

188 (Lungu et al., 2009; Noriega et al., 2008; Noriega et al., 2010a). To the best of our

189 knowledge, it is remarkable that no works were previously developed regarding the

190 genus Staphylococcus. So, in order to know the effect of oxygen concentration on this

191 bacteria development, S. warneri growth was monitored in liquid medium with different

192 concentrations of dissolved oxygen. For these experiments, the liquid medium prepared

193 with whole egg was employed as model of real egg derivatives. As can be observed in

194 Figure 2, although Staphylococcus grew under all assayed aeration levels, the level of

195 growth depended on the oxygen concentration. Specifically, the maximum

196 concentration of bacteria achieved in anoxic conditions was $6.7 \times 10^{5} \mathrm{CFU} / \mathrm{ml}$, whereas

197 in hypoxic and aerobic conditions the maximum concentrations were $2.0 \times 10^{6}$ and

$1981.4 \times 10^{7} \mathrm{CFU} / \mathrm{ml}$, respectively. The effect of oxygen can be also easily noticed

199 considering the specific growth rate at the exponential phase values, since $\mu$ in aerobic

200 conditions is twice the value obtained in hypoxia and it is four times higher than in

201 anoxic conditions (Table 1). 


\subsection{Structured model food: Spanish potato omelette}

\subsubsection{Structure of the model food}

In the micrographs of the potato omelette no differences could be appreciated between the structure of cooked and non-cooked samples, so in Figure 4 it is only 207 shown as an example an image of a non-cooked omelette. Potato cells and also air 208 bubbles originated by the foaming properties of egg can be easily observed. Additionally, higher magnification allowed the observation of isolate coccus of Staphylococcus immersed within the liquid egg (see arrows in Figure 4B).

The experimental data of all frequency sweep tests were correlated to the

212 following power law equation, usually employed to characterise weak gel foods

213 (Gabriele et al., 2001; Laca et al., 2010b; Rodil et al., 2017):

$$
G^{*}=A \cdot v^{1 / z}
$$

where $G^{*}$ is the complex modulus in $\mathrm{Pa}, v$ the frequency in $\mathrm{Hz}, z$ 216 (dimensionless) the coordination number and $A\left(G^{*}\right.$ in $\mathrm{Pa}$ at $\left.1 \mathrm{~Hz}\right)$ the proportional

217 coefficient. The coordination number $(z)$ is a measure of the number of rheological units 218 correlated with one another in the three-dimensional structure, whereas the proportional 219 coefficient $(A)$ is related to the strength of the interaction between those units (Mancini 220 et al. 2002).

It can be noted that values found here for parameters $A$ and $z$ of omelette samples were in the same order of magnitude of those reported by Ndayishimiye et al.

223 (2016) for sweet potato-wheat doughs (A: 7.2-8.9 $\mathrm{kPa} \mathrm{s}^{1 / \mathrm{z}}$ and $\left.z: 5.2-5.7\right)$ and were 224 within the range described by Migliori et al. (2009) for Yorkshire pudding batter 225 prepared with different egg amounts (A: 2.5-31 $\mathrm{kPa} \mathrm{s}^{1 / \mathrm{z}}$ and $\left.z: 2.5-28\right)$ (Table 2). When results obtained for the different samples analysed in the present work are compared, the 
227 rheological parameters indicate the existence of some structural differences between

228 cooked and non-cooked omelettes. Regarding the network extension, $z$ maintained a

229 similar value for the different samples, except for the sample cooked at $100{ }^{\circ} \mathrm{C}$. With

230 respect to the network strength, a clear trend can be observed, since the $A$ value raised

231 when cooking temperature increased. Hence, certain differences could be appreciated

232 between the structure of non-cooked samples and omelettes cooked at $60{ }^{\circ} \mathrm{C}$ and $80{ }^{\circ} \mathrm{C}$,

233 and the differences became more marked for the omelette cooked at higher temperature.

234 Certainly, parameters $A$ and $z$ reflect high structural modifications when the sample was

235 cooked at $100{ }^{\circ} \mathrm{C}$. Specifically, this cooking temperature slightly decreased the number

236 of interacting units in the three-dimensional structure and, at the same time, notably

237 increased the strength of these interactions. This effect can be explained by considering

238 the temperature-induced transitions due to starch and egg gelatinization acting as

239 material network strengthening factors.

\subsubsection{Survival of Staphylococcus after cooking}

The United States Department of Agriculture (USDA) provides minimum

242 temperatures and holding times required to accurately treat liquid egg products.

243 Specifically, whole egg should be treated at $60{ }^{\circ} \mathrm{C}$ for $2.5 \mathrm{~min}$ (Froning et al., 2002).

244 However, not only the setpoint temperature and time have an important effect on

245 thermal inactivation rates of food microorganisms, but other aspects of heating

246 treatment conditions, i.e. heating rate and heating uniformity, are also determinants

247 (Kou et al., 2018). In the present work, it is remarkable that the cooking process carried

248 out for $8 \mathrm{~min}$ at $60^{\circ} \mathrm{C}$ and $80^{\circ} \mathrm{C}$ practically did not affected the number of viable

249 microorganisms in the omelettes, maintaining the inoculation level $\left(\sim 10^{7} \mathrm{CFU} / \mathrm{g}\right)$. It

250 should be pointed out that omelettes are a solid product and the recommendations for

251 egg products pasteurization usually refers to liquid foodstuffs where the convention 
252 plays an important role in the heat transfer. On the contrary, when the omelette was 253 cooked at $100^{\circ} \mathrm{C}$ a reduction of one order of magnitude was achieved decreasing the 254 concentration of viable Staphylococcus from $1.8 \times 10^{7}$ to $2.0 \times 10^{6} \mathrm{CFU} / \mathrm{g}$ (Figure 5).

255 According to the Spanish Government, "in all catering business those foodstuffs 256 elaborated with fresh eggs should be cooked at least at $75^{\circ} \mathrm{C}$ " (R.D. 1254/1991). Thus, 257 temperatures higher than $75{ }^{\circ} \mathrm{C}$ are recommended in order to assure that $75^{\circ} \mathrm{C}$ are 258 achieved at the internal area of the product, especially if the cooking time is short. 259 Despite this regulation, in some European countries, including Spain, it is a usual 260 practice that egg products are consumed without being totally cooked (soft-boiled eggs, 261 "runny" omelettes...) not only at households, but also at restaurants and canteens, 262 increasing food poisoning risks.

\subsubsection{Development of Staphylococcus during storage}

A frequent custom in households and also in eating establishments is to store the Spanish potato at room temperature. Simulating a contamination by Staphylococcus, in Figure 4 it is shown the bacterial growth at $20^{\circ} \mathrm{C}$ at different longitudinal positions in

267 model omelettes cooked at different temperatures $\left(60,80\right.$ and $\left.100{ }^{\circ} \mathrm{C}\right)$. The highest 268 bacterial concentration was achieved in the surface for the omelette cooked at $60{ }^{\circ} \mathrm{C}$ with an increase of one order of magnitude. The middle and bottom positions show identical behaviour with a growth slightly lower. Qualitatively, similar behaviours can

271 be observed in the three positions analysed of samples cooked at 80 and $100{ }^{\circ} \mathrm{C}$.

272 Nevertheless, when the lag phase and the specific growth rates are analysed in detail,

273 some differences can be observed (Table 1). It is remarkable that in the three omelettes cooked at different temperature there was not detected a lag phase in the samples taken

275 from the surface, whereas a lag phase of approximately $24 \mathrm{~h}$ was observed in the inner 276 positions. It seems that in this solid media, the absence of oxygen provoked the 
277 enlargement of this lag phase. With regards to the specific growth rates, similar values were found for each cooking temperature independently of the longitudinal position.

279 Comparing the $\mu$ obtained for the different omelettes, those cooked at 60 and $80{ }^{\circ} \mathrm{C}$ 280 showed similar values $\left(0.026-0.029 \mathrm{~h}^{-1}\right)$, quite close to those found in liquid medium 281 under anoxic conditions $\left(0.024 \mathrm{~h}^{-1}\right)$. This indicates that, although the surface is in 282 contact with air, and this higher availability of oxygen makes cell growth starts more 283 quickly, diffusional limitations exist even in the surface position (thickness $0.3 \mathrm{~cm}$ ) contributing to a slower bacterial growth.

Other aspect to take into account is the confinement of the bacteria inside a structured media, which can also have influence on cell growth rate (Noriega et al., 287 2010b). In this sense, the omelette treated at $100{ }^{\circ} \mathrm{C}$ exhibited lower values of the 288 specific growth rate $\left(0.014-0.017 \mathrm{~h}^{-1}\right)$. This seems to corroborate the results found by rheological measurements, which indicated some changes on the structure of the omelette treated at $100^{\circ} \mathrm{C}$. Aspridou et al. (2014) studied the effect of the microstructure

291 of the medium on the growth of Listeria monocytogenes. They reported that the growth 292 of the pathogen was faster in the liquid than in the gelled systems. In a similar manner, 293 here, the growth of $S$. warneri was faster in liquid medium in comparison with the 294 omelette, which is clearly affected by the network formed between egg proteins and 295 starch.

With the aim to evaluate the effect of storage temperature when an accidental 297 contamination with Staphylococcus takes place, model omelettes inoculated with S. 298 warneri and cooked at $60{ }^{\circ} \mathrm{C}$ during $8 \mathrm{~min}$ have been incubated at refrigerated 299 conditions $\left(6^{\circ} \mathrm{C}\right)$ and room temperatures $\left(20\right.$ and $\left.30^{\circ} \mathrm{C}\right)$. As can be observed in Figure 3006 , the growth at refrigerated temperature $\left(6^{\circ} \mathrm{C}\right)$ was very slow, being similar in all the 301 positions studied and in the same order of magnitude as the initial concentration. At 
302 simulated room temperatures $\left(20^{\circ} \mathrm{C}\right.$ and $\left.30^{\circ} \mathrm{C}\right)$ the cell growth were higher in all the 303 positions, achieving values around $10^{8} \mathrm{CFU} / \mathrm{mL}$ in $72 \mathrm{~h}$. Clear differences can be 304 observed with respect to the lag phase that was shorter for higher temperatures and 305 oxygen availability. Indeed, at $6{ }^{\circ} \mathrm{C}$ the microorganism showed a lag-phase of $24 \mathrm{~h}$ in 306 the surface, whereas at middle and bottom positions it lasted 48 hours. At $20^{\circ} \mathrm{C}$ there 307 was no lag-phase in the surface and it lasted 24 hours at middle and bottom positions, 308 whereas at $30{ }^{\circ} \mathrm{C}$ lag-phase was not observed for any of the analysed positions. As expected, the specific growth rates were very different depending on the 310 storage temperature. So, the ranges for $\mu$ values were $0.018-0.022 \mathrm{~h}^{-1}, 0.028-0.029 \mathrm{~h}^{-1}$ 311 and $0.034-0.046 \mathrm{~h}^{-1}$ for 6,20 and $30^{\circ} \mathrm{C}$, respectively. Differences for the longitudinal

312 position only were detected for the highest temperature, where the growth was faster on 313 the surface. As explained in previous works (Noriega et al., 2008; Noriega et al., 314 2010a), the reason is that just on the surface there is no problem with the availability of 315 oxygen, whereas in the inner positions diffusional limitations exits, which makes the 316 bacterium grow slower. Since the absence of diffusional limitations only occurs in the 317 very narrow layer close to the surface and the layer analysed had around $0.3 \mathrm{~cm}$ of 318 thickness, the preferential growth on the surface only could be observed when the effect 319 of oxygen availability on bacterial growth was more marked, i.e. at $30^{\circ} \mathrm{C}$.

320 It is obvious that the long duration of the lag-phase and the lower $\mu$ value at 321 refrigerated temperatures entailed a lower growth of Staphylococcus in comparison to 322 room temperatures. In this context, the Spanish Government (R.D. 1254/1991) 323 established that the foodstuffs which included fresh eggs as ingredient must be 324 consumed within the following 24 hours to their elaboration and they must be preserved 325 at $8^{\circ} \mathrm{C}$ until their consumption. With this regards, it should be noticed that in 24 hours 
326 the growth of the bacteria is negligible in all the studied positions at $6{ }^{\circ} \mathrm{C}$ of storage 327 (Figure 6).

328 So, regarding storage conditions, it can be concluded that the lack of oxygen is 329 not an effective measure to avoid the growth of Staphylococcus genus. On the contrary, 330 refrigeration is determinant to reduce the growth rates of microorganisms. Thus, the 331 storage of egg and egg products refrigerated is key to reduce food poisoning risk, not 332 only at household level, but also at restaurant, hotel and catering sectors.

\section{CONCLUSIONS}

S. warneri was not able to growth in a liquid medium mainly composed of egg white due to the antimicrobial effects of albumen proteins. On the contrary, yolk showed to be an accurate substrate for the development of the bacteria. When a mixture of yolk and albumen was employed as liquid media, it was proved that Staphylococcus growth was strongly favoured by the amount of dissolved oxygen which was clearly reflected by the specific growth rates at the exponential phase.

In solid foods (i.e. model potato omelette), it was found that the cooking at $100^{\circ} \mathrm{C}$ during 8 min achieved a reduction of one order of magnitude in the concentration

344 of bacteria, whereas cooking at lower temperatures did not affect bacterial viability. In 345 addition, the structure of omelettes cooked at $100^{\circ} \mathrm{C}$ changed, as it was reflected by 346 rheological measurements. This structural change exerted a great influence on the 347 specific growth rates of Staphylococcus that were lower than half the value obtained with lower cooking temperatures. While anaerobic conditions are not an effective barrier against the growth of Staphylococcus, refrigerate temperature of storage is a determinant measure to take into account in order to avoid food outbreaks originated by 
351 this genus. Thus, from a practical perspective it results essential that, in any

352 environment (household, catering industry) egg products should not be stored at room 353 temperatures even for a few hours.

354

355 AKNOWLEDGEMENTS

356

357

358

359

360

361

362

363

364

365

366

367

This study was developed thanks to funding from the Economy and Employment

Office of Principality of Asturias (Spain) through project GRUPIN14-140.

\section{REFERENCES}

Abín, R., Laca, A., Laca, A., Díaz, M., 2018. Environmental assessment of intensive egg production: A Spanish case study. J. Clean. Prod. 179, 160-168.

Al-Ajeeli, M.N., Taylor, T.M., Alvarado, C.Z., Coufal, C.D., 2016. Comparison of eggshell surface sanitization technologies and impacts on consumer acceptability. Poult. Sci. 95, 1191-1197.

Alter, T., 2017. Chapter 6 - Prevention and mitigation strategies for Campylobacter with focus on poultry production. In: Klein, G. (Ed.), Campylobacter. Acadeic Press, USA, pp. 111-129.

Ananou, S., Rivera, S., Madrid, M.A., Maqueda, M., Martínez-Bueno, M., Valdivia, E., 2018. Application of enterocin AS-48 as biopreservative in eggs and egg fractions: Synergism through lysozyme. LWT-Food Sci. Technol. 89, 409-417.

Baron, F., Nau, F., Guérin-Dubiard, C., Bonnassie, S., Gautier, M., Andrews, S.C., Jan, S., 2016. Egg white versus Salmonella Enteritidis! A harsh medium meets a resilient pathogen. Food Microbiol. 53, 82-93. 

of the substrate's microstructure on the growth of Listeria monocytogenes. Food Res. Int. 64, 683-691. lipopolysaccharide in laying hens stimulates antimicrobial properties of egg white against Staphylococcus aureus. Vet. Immunol. Immunopathol. 152, 225-236.

De Reu, K.; Grijspeerdt, K.; Messens, W.; Heyndrickx, M.; Uyttendaele, M.;

Debevere,J.; Herman, L., 2006. Eggshell factors influencing eggshell penetration and

Food Microbiol. 112, 253-260.

Froning, G.W., Peters, D., Muriana, P., Eskridge, K., Travnicek, D., Sumner,

S.S., 2002. Internationals egg pasteurization manual. United Egg Association, American

Egg Board, US Poultry and Egg Association, Australian Egg Board, International Egg Commission.

Gabriele D, de Cindio B, D’Antona P., 2001. A weak gel model for foods. Rheol. Acta 40, 120-127. Gast, R.K., Jones, D.R., 2017. Salmonella and impact on Egg Production. In:

Hester, P. (Ed.), Egg Innovations and Strategies for Improvements. Academic Press, USA, pp. 515-521. Ball, T.A., Jin, T.Z., 2015. Salmonella isolated from ready-to-eat pasteurized liquid egg

396 products: Thermal resistance, biochemical profile, and fatty acid analysis. Int. J. Food Microbiol. 206, 109-117. 
and antimicrobial resistance of Campylobacter species isolated from the avian eggs.

$400 \quad$ Food Control 70, 35-40.

hens and egg production: incidence and potential issues. In: Ricke, S.C., Gast, R.K.

(Eds.), Producing safe eggs-microbial ecology of Salmonella. Academic Press, USA, pp. 235-256.

Kou, X., Li, R. Hou, L., Zhang, L., Wang, S., 2018. Identifying possible nonthermal effects of radio frequency energy on inactivating food microorganisms. Int. J. Food Microbiol. 269, 89-97.

Laca A, Paredes B, Díaz M., 2010a. A method of egg yolk fractionation. Characterization of fractions. Food Hydrocolloid. 24, 434-443.

Laca A, Sáenz, M.C., Paredes B, Díaz M., 2010b. Rheological properties,

411 stability and sensory evaluation of low-cholesterol mayonnaises prepared using egg 412 yolk granules as emulsifying agent. J. Food Eng. 97, 243-252.

Lechevalier, V., Guérin-Dubiard, C., Anton, M., Beaumal, V., Briand, E.D., 414 Gillard, A., Gouar, Y.L., Musikaphun, N., Tanguy, G., Pasco, M., Dupont, D., Nau, F., 2017. Pasteurisation of liquid whole egg: Optimal heat treatments in relation to its functional, nutritional and allergenic properties. J. Food Eng. 195, 137-149.

418 pathogenesis of Listeria monocytogenes under low oxygen or anaerobic conditions: A 419 review. Anaerobe 15, 7-17. 
424 in table egg production in the United Kingdom and Europe. Pages 3-23. In: Ricke, S.C., 425 Gast, R.K. (Ed.), Producing safe eggs-microbial ecology of Salmonella. Academic Press, USA, pp. 3-23. Messelhäusser, U., Thärigen, D., Elmer-Englhard, D., Bauer, H., Schreiner, H., Höller, C., 2011. Occurrence of thermotolerant Campylobacter spp. on eggshells: A missing link for food-borne infections? Appl. Environ. Microbiol. 77, 3896-3897. Migliori, M., Gabriele, D., Baldino, N., Lupi, F.R., De Cindio, B., 2009. Rheological properties of batter dough: Effect of egg level. J. Food Process Eng. 34, $1266-1281$. contamination of eggs and behaviour of poultry flocks in the free range environment. Comp. Immunol. Microbiol. Infect. Dis. 49, 88-94.

Muñoz, A., Dominguez-Gasca, N., Jimenez-Lopez, C., Rodriguez-Navarro, A.B., 2015. Importance of eggshell cuticle composition and maturity for avoiding transshell Salmonella contamination in chicken eggs. Food Control 55, 31-38.

Ndayishimiye, J.B., Huang, W.N., Wang, F., Chen, Y.Z., Letsididi, R., Rayas440 Duarte, P., Ndahetuye, J.B., Tang, X.J., 2016. Rheological and functional properties of composite sweet potato - wheat dough as affected by transglutaminase and ascorbic acid. J. Food Sci. Technol. 53, 1178-1188.

Neira, C., Laca, A., Laca, A., Díaz, M., 2017. Microbial diversity on commercial eggs as affected by the production system. A first approach using PGM. Int. J. Food Microbiol. 262, 3-7.

Noriega, E., Laca, A., Díaz, M., 2008. Modelling of diffusion-limited growth for

447 food safety in simulated cheeses. Food Bioprod. Process. 86, 122-129. 
449 for the competitive growth of Listeria innocua in minced chicken breasts. Int. J. Food 450 Microbiol. 142, 44-52. Noriega, E., Laca, A., Díaz, M., 2010b. Decisive role of structure in food microbial colonization and implications for predictive microbiology. J. Food Prot. 73, 938-951.

Fate of mesophilic aerobic bacteria and Salmonella enterica on the surface of eggs as affected by chicken feces, storage temperature, and relative humidity. Food Microbiol. 48, 200-205.

Silvetti, T., Morandi, S., Hintersteiner, M., Brasca, M., 2017. Use of hen egg white lysozyme in the food industry. In: Hester, P. (Ed.), Egg Innovations and 460 Strategies for Improvements. Academic Press, USA, pp. 233-242.

462 approaches for improving postharvest safety of egg and egg products. In: Ricke, S.C., 463 Gast, R.K. (Eds.), Producing safe eggs-microbial ecology of Salmonella. Academic 464 Press, USA, pp. 391-420.

465 Wang, J., Yue, H., Wu, S., Zhang, H., Qi, G., 2017a. Nutritional modulation of 466 health, egg quality and environmental pollution of the layers. Anim. Nutr. 3, 91-96.

467 Wang, X., Du, H., Xu, Y., 2017b. Source tracking of prokaryotic communities in 468 fermented grain of Chinese strong-flavor liquor. Int. J. Food Microbiol. 244, 27-35. 
Table 1. Specific growth rate $(\mu)$ values at the exponential phase of growth, obtained from the different conditions assayed. In all cases $\mathrm{CV}<5 \%$ and $\mathrm{r}^{2} \geq \mathbf{0 . 9 1}$.

\begin{tabular}{|c|c|c|c|c|}
\hline Culture medium & Longitudinal position & Incubation conditions & Lag phase (h) & $\mu\left(h^{-1}\right)$ \\
\hline \multirow{3}{*}{ Liquid yolk } & \multirow[t]{3}{*}{ 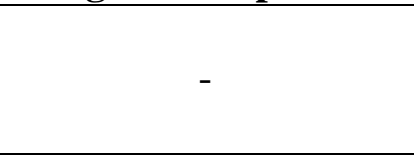 } & $11^{\circ} \mathrm{C} / 250 \mathrm{rpm}$ & \multicolumn{2}{|c|}{ No growth was observed } \\
\hline & & $25^{\circ} \mathrm{C} / 250 \mathrm{rpm}$ & 10 & 0.3172 \\
\hline & & $37^{\circ} \mathrm{C} / 250 \mathrm{rpm}$ & - & 0.2810 \\
\hline \multirow{3}{*}{$\begin{array}{c}\text { Liquid egg } \\
\text { (yolk + albumen) }\end{array}$} & \multirow{3}{*}{-} & $20^{\circ} \mathrm{C} / 250 \mathrm{rpm}$ (aerobic) & 3 & 0.0837 \\
\hline & & $20^{\circ} \mathrm{C} / 0 \mathrm{rpm}$ (hypoxic) & 3 & 0.0409 \\
\hline & & $20^{\circ} \mathrm{C} / 0 \mathrm{rpm}$ (anoxic) & 4 & 0.0237 \\
\hline \multirow{9}{*}{$\begin{array}{l}\text { Model omelette } \\
\left(\text { cooked at } 60^{\circ} \mathrm{C}\right)\end{array}$} & Surface & \multirow{3}{*}{$6^{\circ} \mathrm{C}$} & 24 & 0.0176 \\
\hline & Middle & & 48 & 0.0220 \\
\hline & Bottom & & 48 & 0.0210 \\
\hline & Surface & \multirow{3}{*}{$20^{\circ} \mathrm{C}$} & - & 0.0282 \\
\hline & Middle & & 24 & 0.0289 \\
\hline & Bottom & & 24 & 0.0288 \\
\hline & Surface & \multirow{3}{*}{$30^{\circ} \mathrm{C}$} & - & 0.0461 \\
\hline & Middle & & - & 0.0338 \\
\hline & Bottom & & - & 0.0378 \\
\hline \multirow{3}{*}{$\begin{array}{l}\text { Model omelette } \\
\left(\text { cooked at } 80^{\circ} \mathrm{C}\right)\end{array}$} & Surface & \multirow{3}{*}{$20^{\circ} \mathrm{C}$} & - & 0.0274 \\
\hline & Middle & & 24 & 0.0274 \\
\hline & Bottom & & 24 & 0.0262 \\
\hline \multirow{3}{*}{$\begin{array}{l}\text { Model omelette } \\
\left(\text { cooked at } 100^{\circ} \mathrm{C}\right)\end{array}$} & Surface & \multirow{3}{*}{$20^{\circ} \mathrm{C}$} & - & 0.0176 \\
\hline & Middle & & 24 & 0.0143 \\
\hline & Bottom & & 24 & 0.0165 \\
\hline
\end{tabular}


Table 2. Power-law parameters obtained from frequency sweeps. Average values \pm SD are reported. In all cases $r^{2} \geq 0.993$.

\begin{tabular}{ccc}
\hline POTATO OMELETTE & \multicolumn{2}{c}{ Power-law parameters } \\
\cline { 2 - 3 } & $\boldsymbol{A}\left(\mathbf{k P a ~ s}^{\mathbf{1 / \mathbf { z }}}\right)$ & $\boldsymbol{z}$ \\
\hline Non-cooked & $4.5 \pm 0.3$ & $11.4 \pm 0.3$ \\
\hline Cooked at $\mathbf{6 0}^{\circ} \mathbf{C}$ & $5.6 \pm 1.8$ & $11.3 \pm 0.5$ \\
\hline${\text { Cooked at } \mathbf{8 0}^{\circ} \mathbf{C}}^{\mathbf{C}}$ & $5.9 \pm 0.1$ & $11.3 \pm 0.3$ \\
\hline Cooked at $\mathbf{1 0 0}^{\circ} \mathbf{C}$ & $8.3 \pm 0.2$ & $10.8 \pm 0.5$ \\
\hline
\end{tabular}




\section{FIGURE CAPTIONS}

Figure 1. Scheme of model omelette and sampling positions.

Figure 2. Growth of $S$. warneri in liquid: yolk- (full symbols) and albumen-medium (empty symbols) in aerobic conditions at different temperatures: $11^{\circ} \mathrm{C}$ (circle), $25^{\circ} \mathrm{C}$ (square) and $37^{\circ} \mathrm{C}$ (triangle). In all cases $\mathrm{CV}>5 \%$.

Figure 3. Growth of $S$. warneri in liquid egg-medium at $20^{\circ} \mathrm{C}$ : Aerobic conditions ( $\square)$, Hypoxic conditions $(\circ)$ and Anoxic conditions $(\Delta)$. In all cases $\mathrm{CV}>5 \%$.

Figure 4. Structured omelette micrographs. A: magnification 10x and B: magnification 100x.

Figure 5. Growth of $S$. warneri at $20^{\circ} \mathrm{C}$ in model omelet at different longitudinal positions: A) surface, B) middle and $C$ ) bottom, cooked at different temperatures: $60{ }^{\circ} \mathrm{C}(\square), 80^{\circ} \mathrm{C}(\Delta)$ and $100{ }^{\circ} \mathrm{C}(\bullet)$. In all cases $\mathrm{CV}>5 \%$.

Figure 6. Growth of $S$. warneri cooked at $60^{\circ} \mathrm{C}$ in model omelet at different longitudinal positions: A) surface, B) middle and C) bottom, incubated at different temperatures: $6{ }^{\circ} \mathrm{C}(\square), 20^{\circ} \mathrm{C}(\Delta)$ and $30^{\circ} \mathrm{C}(\bullet)$. In all cases $\mathrm{CV}>5 \%$. 
Figure 1

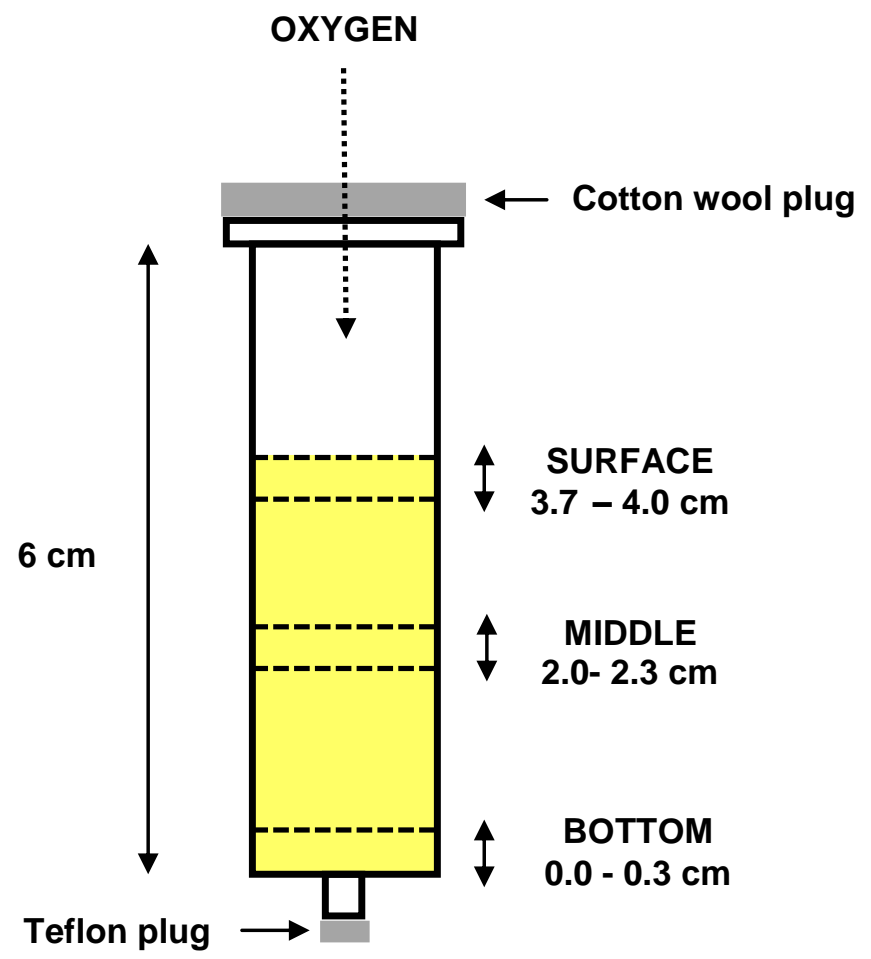


Figure 2

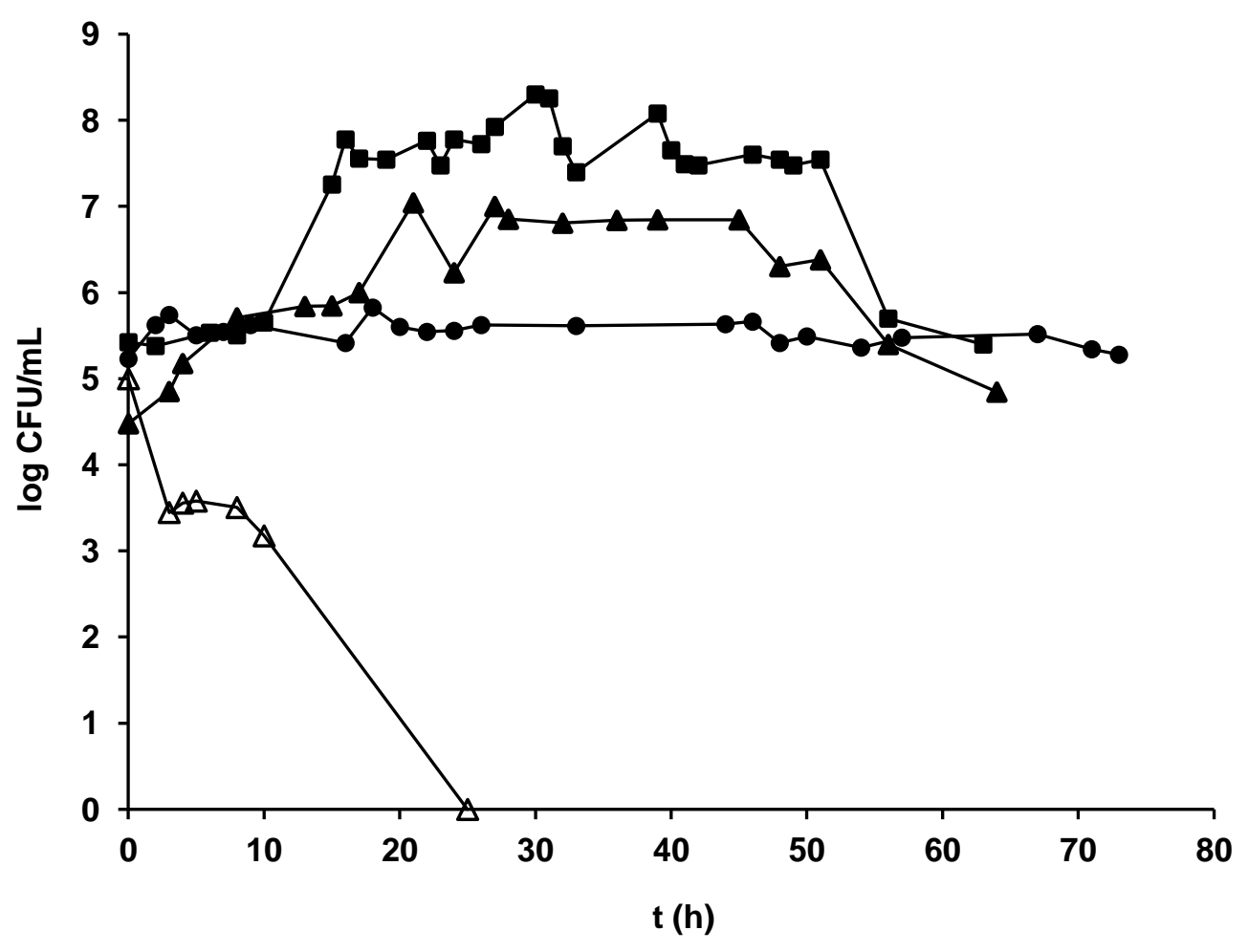


Figure 4
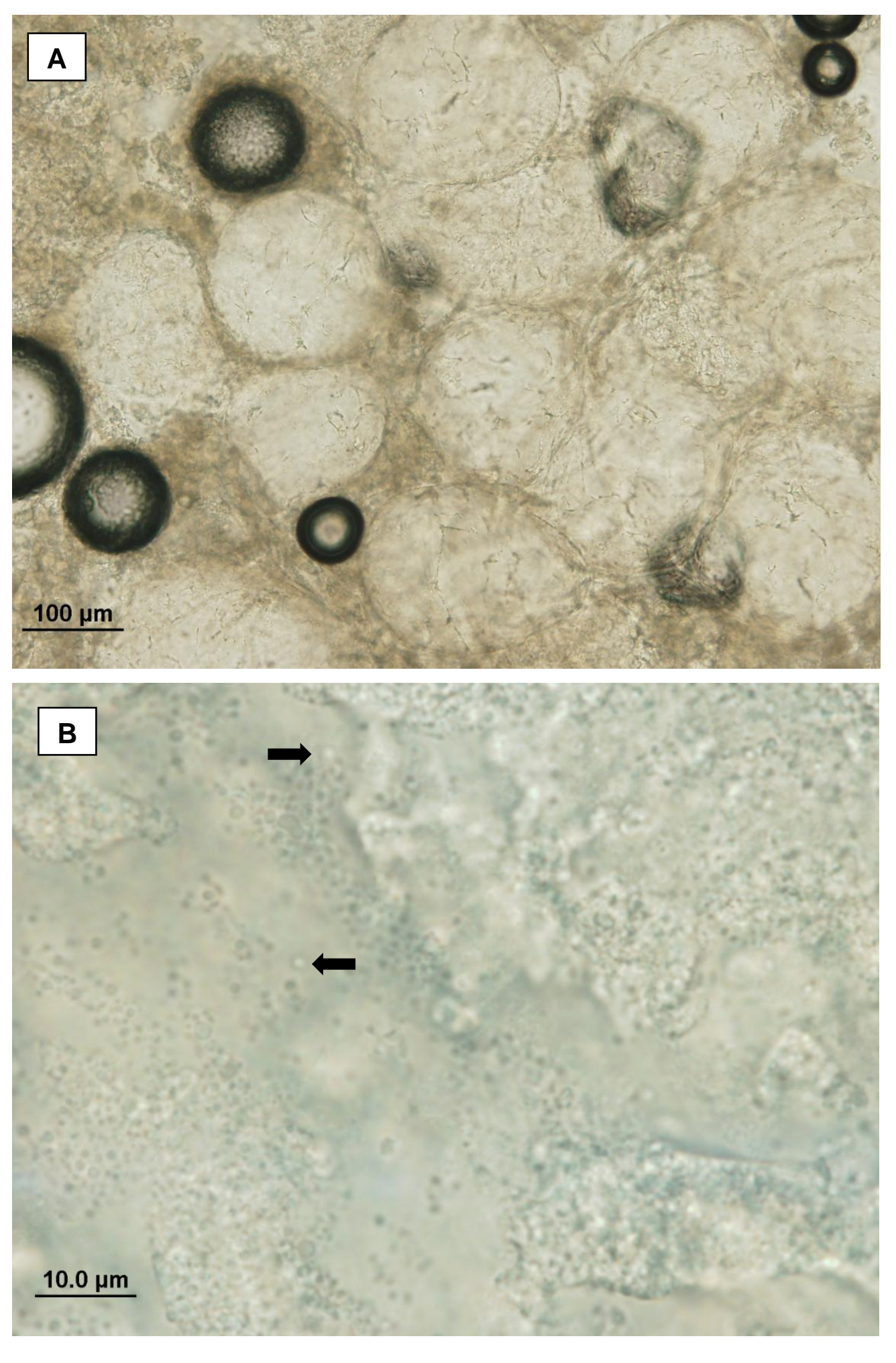
Figure 5

A)

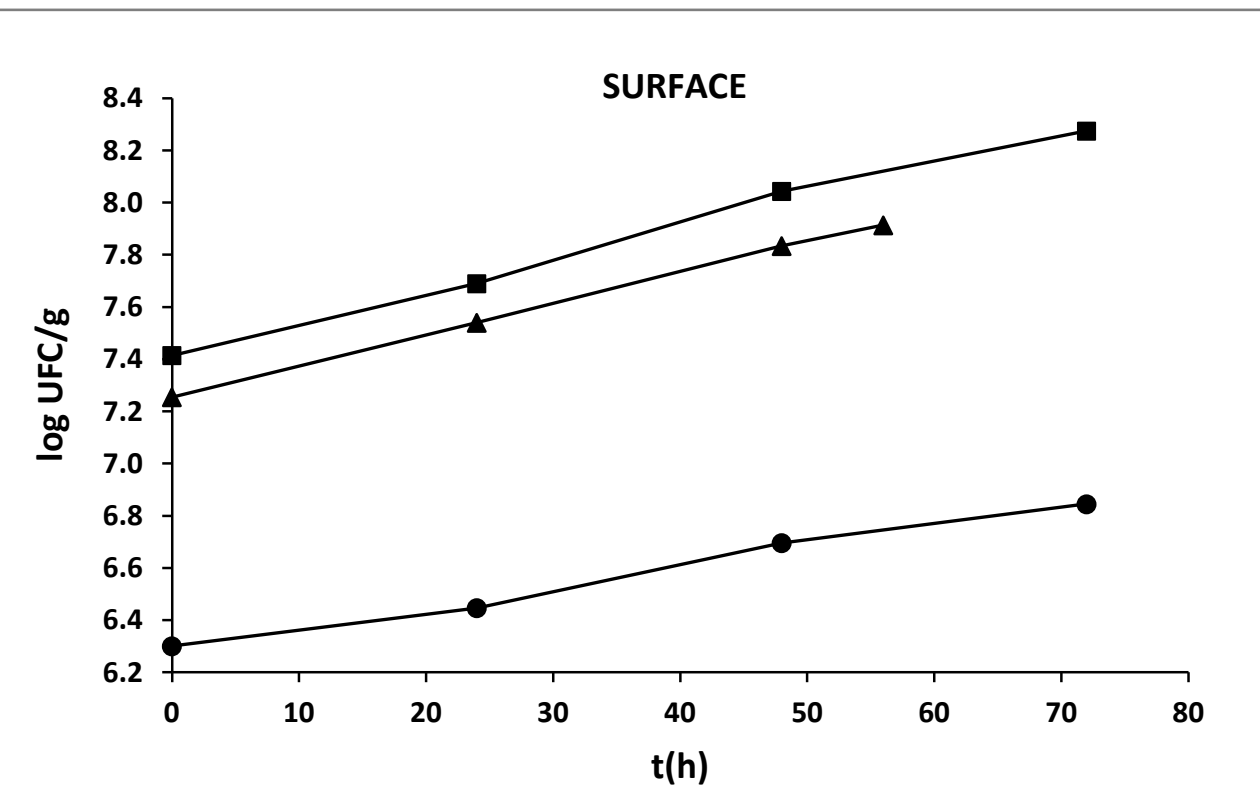

B)

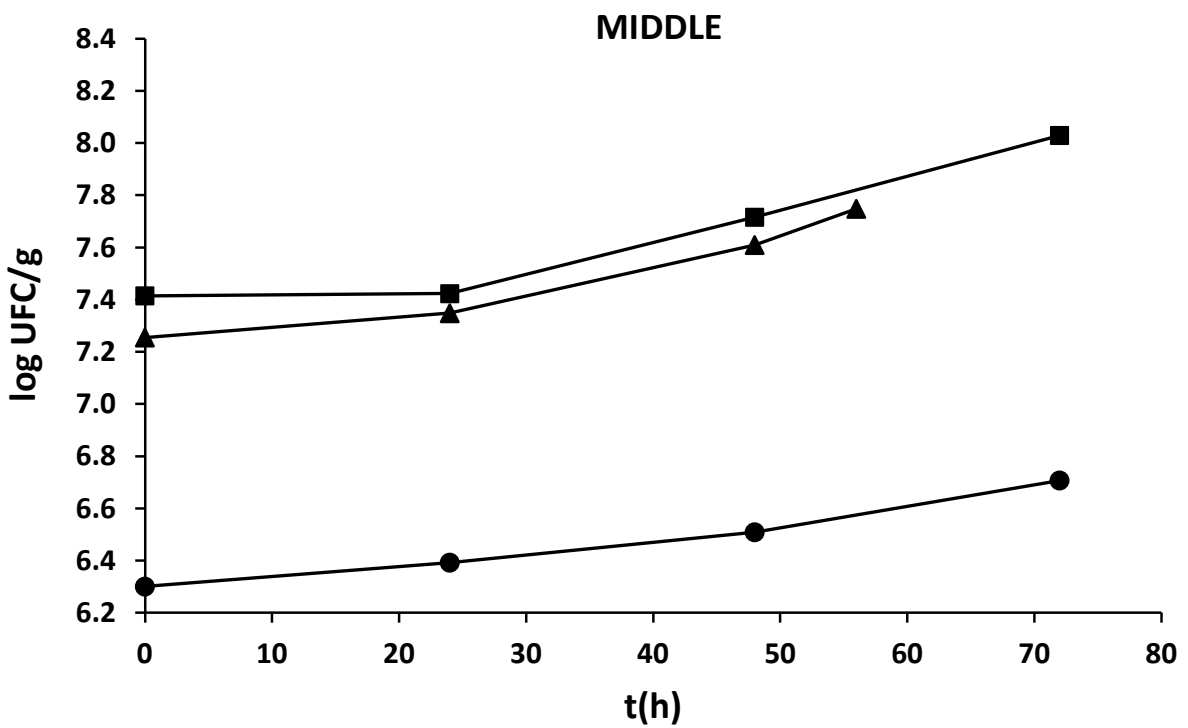

C)

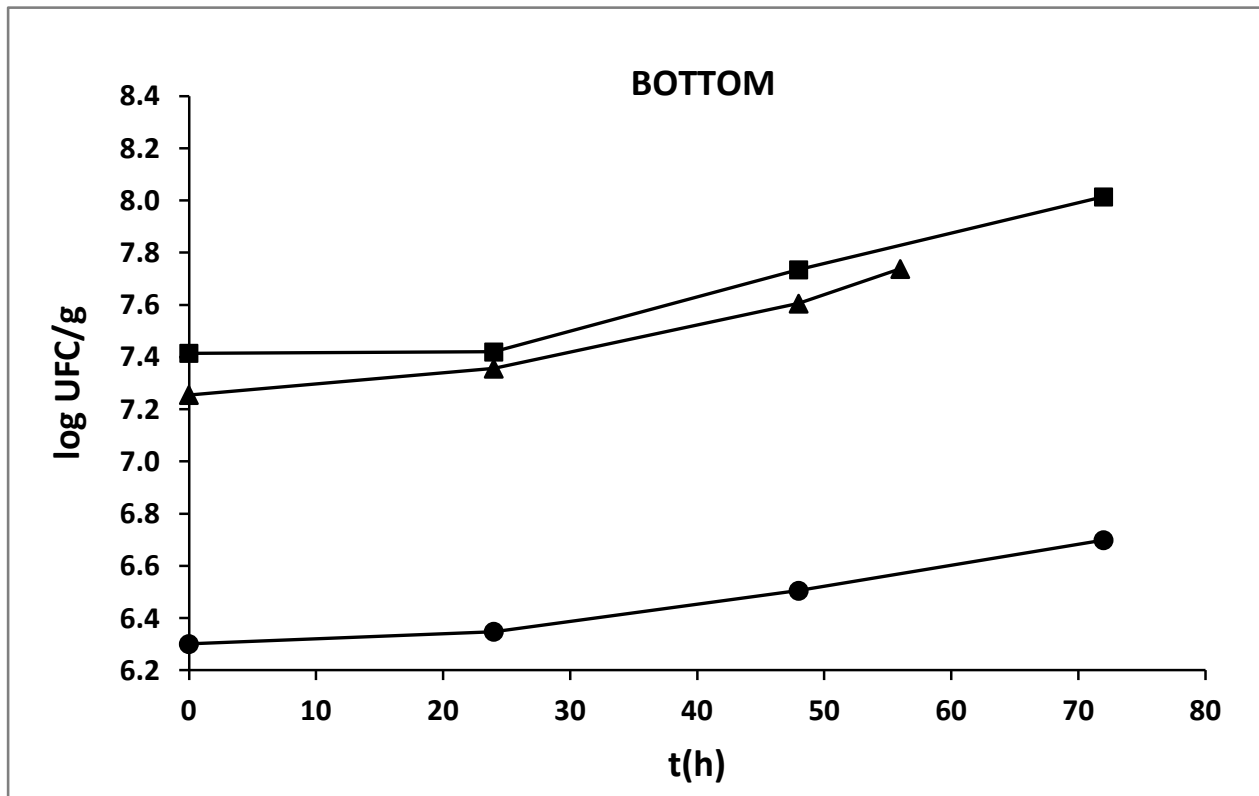


Figure 6

A)
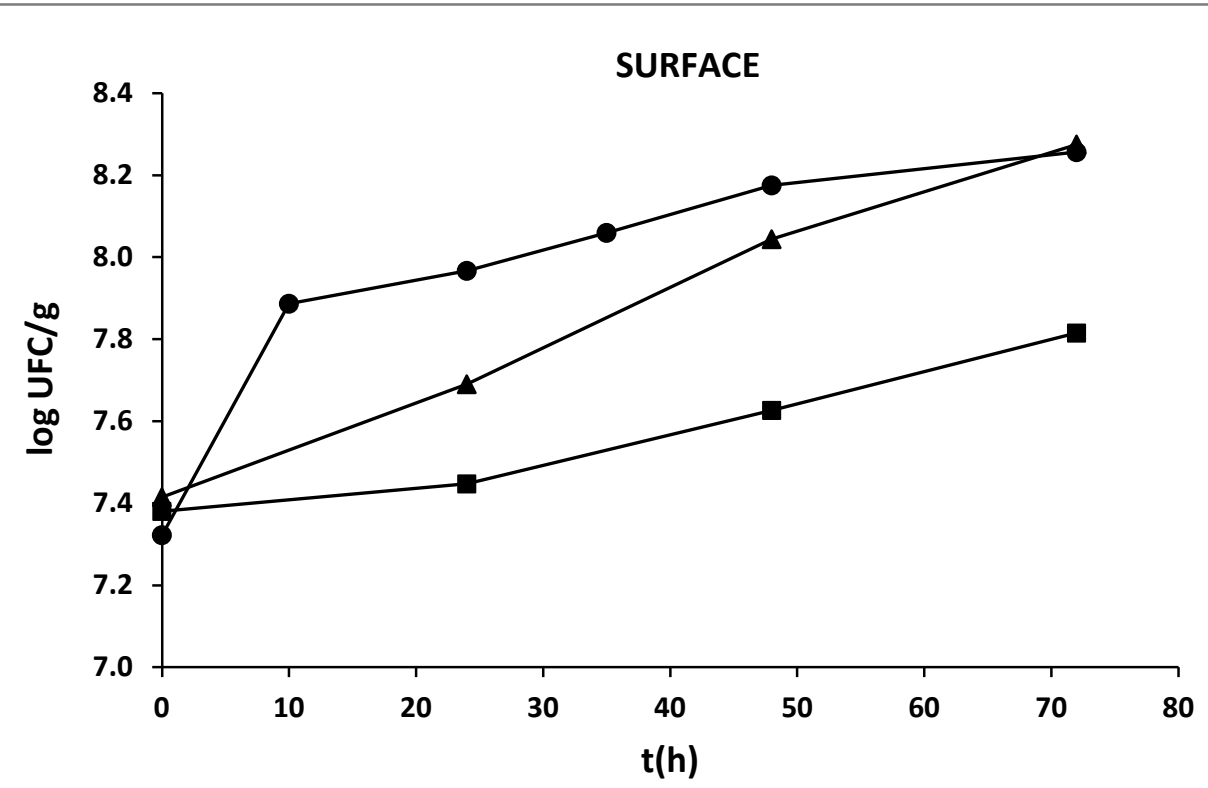

B)

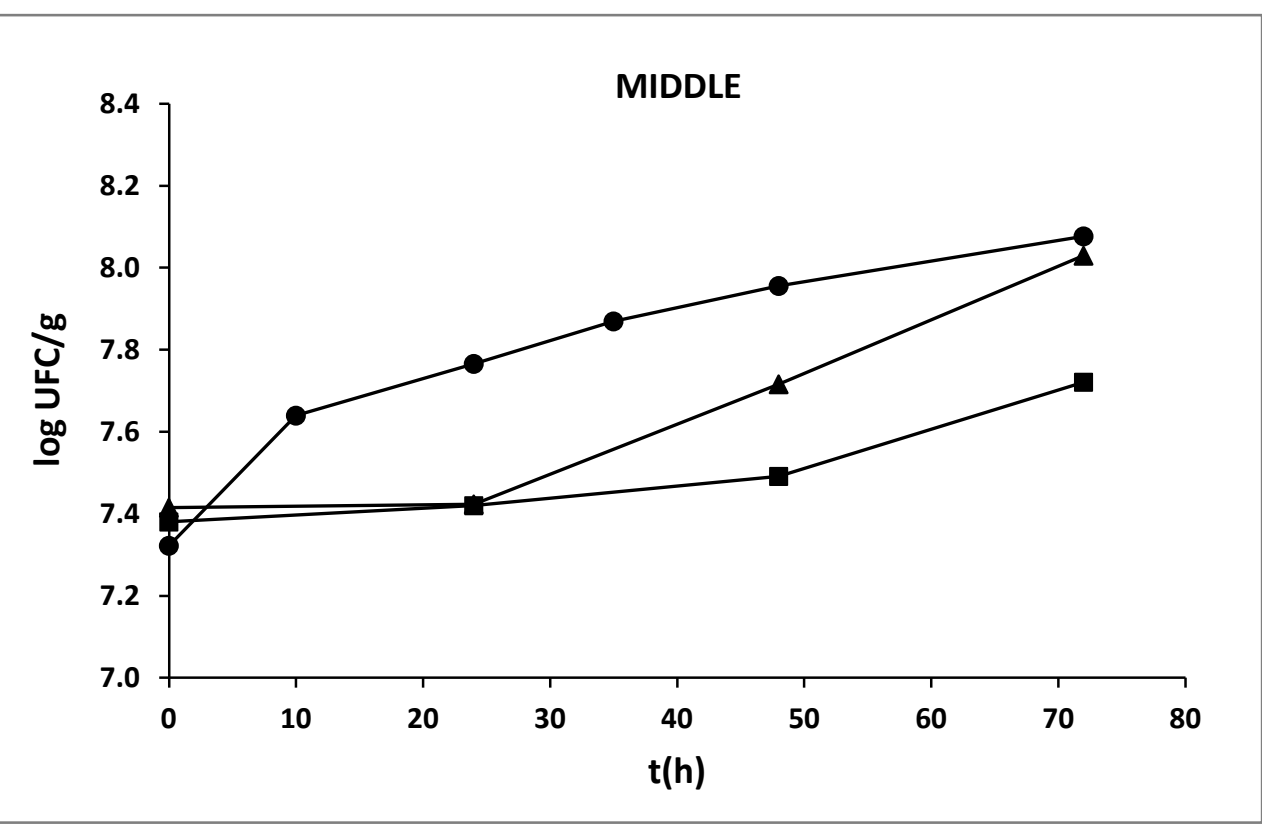

C)
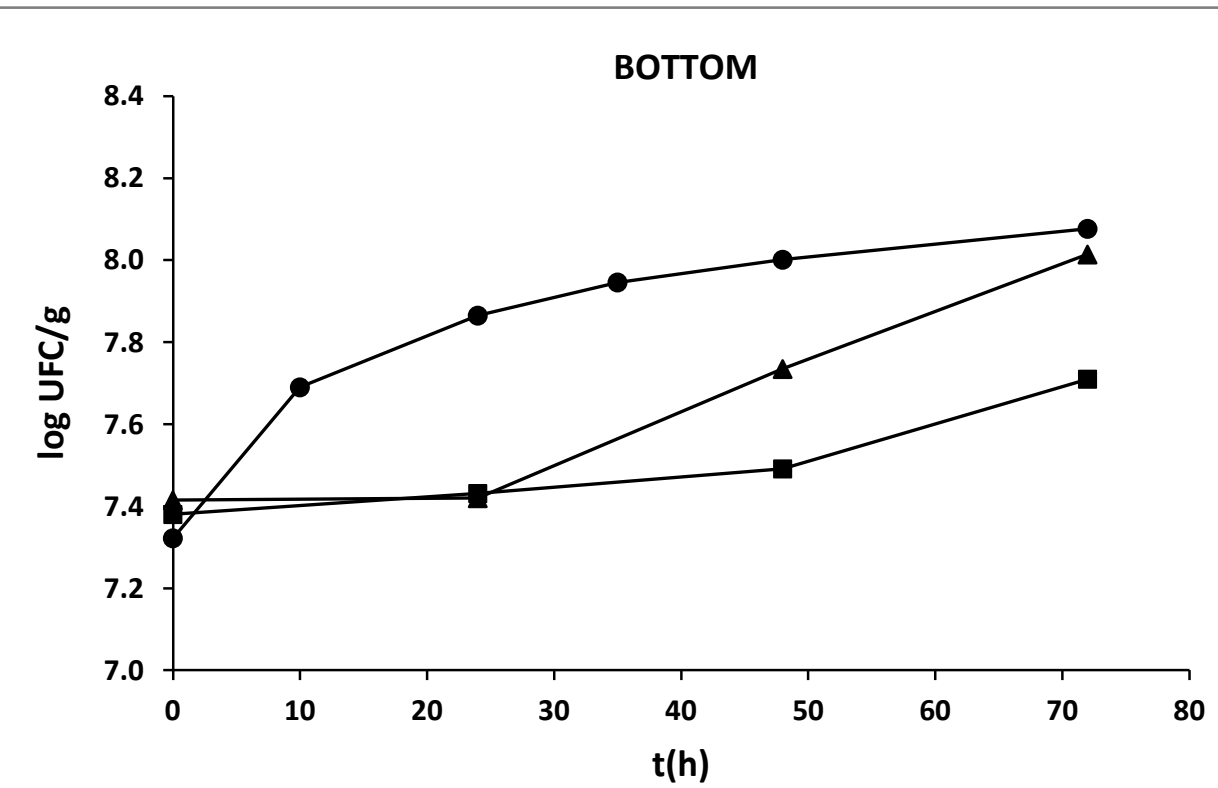